\title{
A Centenary Conference on Marx Norman Levine
}

University of Maryland, Baltimore County

On April 15th and 16th, 1983, a commemorative colloquium, "Marxism: One Hundred Years After" was held at the University of Maryland Baltimore County to mark the hundredth anniversary of the death of Karl Marx. I had organized the conference with a grant from the Maryland Committee for the Humanities, a state funding agency which receives its money from NEH.

Five hundred people attended the conference. An age differential clearly distinguished the audience, as most of those in attendance were forty-five or over. The dividing line seems to have been the Vietnamese War. Young people today are more conservative, worried about unemployment, and not politically sensitive. Those who had personal contact with the Vietnamese era, with the radicalism of the 1960s, are most receptive to an analysis of Marx. Contemporary American radicalism is no longer an affair of the young. Gerontologically and economically it is probably a phenomenon of middle-age and middle-income America.

With a political history including Agnew and Mendel, Maryland is not a vanguard of enlightened, progressive politics. When word of the conference began to spread in the Baltimore area, the radical right began to organize and attempt to suppress it. Political pressure was exerted from the highest levels of government. Members of the staff of Senators Denton and Hatch actually called the Maryland Committee for the Humanities to see whether it was possible to rescind the initial award. Politically, the central issue was the source of the grant money. Members of the Maryland state legislature, as well as assistants in the Governor's office, called the University of Maryland to inquire whether state money was being used. Since the money was basically federal, the state could not squelch the conference. In this instance, bureaucracy worked in support of radicalism. Complaints to the NEH itself were undoubtedly lost in the administrative maze, and although there was much sound and fury the conference went off without interference.

The conference was divided into four parts: Marxism and Work, Marxism and Feminism, Marxism and Religion, and Marxism and Black Culture. These themes were chosen for revisionist purposes: classical Marxism had difficulty in grasping the problems of feminism, racism, religion, and white-collar labor and contemporary Marxism must modify its understanding of as well as be modified by these same forces. But the highlight of the conference for me was the statement that it made about the status of Marxist studies in America today. With all the political pressure brought on the University of Maryland Baltimore County about the conference, the administration never brought any pressure on me in any way, shape or 
form. Marxist studies within the American university is positioned as a tolerant tokenism. The age of McCarthy is past. Outright repression is considered bad taste; it has been replaced by a grudging toleration within certain limits. One of these limits is: that the Marxist professor does not become politically active, foment student unrest. This much of the $60 \mathrm{~s}$ hangs on, and if the professor renounces his activist role he is free to pursue his academic Marxism. Contemporary American university Marxism has been de-politicized and confined to the publishing houses and journals. Another limit is: Marxism must remain a minority within the American university. Tokenism means that it is stylish. a sign of the liberated mind, to allow for the articulation of dissenting ideas in the university. Nevertheless, there have been gains under the policy of tokenism. Most American universities have their Marxists. like most American universities have their black. But it is common now for a university campus to have its Marxist professor, one in each department.

The radicalism of the $1980 \mathrm{~s}$ is vastly different than the protests of the $1960 \mathrm{~s}$. Radicalism is not dead, it has just altered its form. Students led the radical protest of the 1960s. When America was not overthrown, many of these students went on for Ph.D.'s so they could feed their stomachs. Many of these radical Ph.D.'s never received tenure while others successfully crossed over into this magic circle. The tenure transcendence has stamped American Marxism today. Job security has allowed the attitudinal Marxist to be also a creative and functioning Marxist. In the 1960 s the students were ahead of the university. In the 1980s, the Marxist in the university is ahead of the student and the rest of society. Marxism in America today is situated in a minority intellectual elite which is alienated from its surrounding society. In America, Marxism has become the presence of a small academic intelligentsia. This is what the policy of tokenism has wrought. This is the first time in American history when a Marxist intelligentsia has existed in the university, even if it is the policy of the university to keep it a permanent minority. Marxist dissent is tenured: that is, it is continuing, persistent, a fact of American cultural life. protected and nurtured by the traditions, as the conference "Marxism: One Hundred Years After" was, of academic freedom. 